\title{
DANTir
}

\section{Văn minh làm giàu từ góc nhìn của một người Việt}

(Dân trí) - Bạn hãy thư hình dung một bức tranh thể hiện hình ảnh một thưong gia cười một chú lạc đà. Dưới chân ho chỉ có cát nóng bỏng của sa mạc khô cằn, phía sau lung ho là ánh mặt chời chói lòa, bỏng rát. Hai bên đường chỉ có sưong rồng gai góc, nhu biểu trung cho hành trình vất vả đầy chông gai. Một điều gây bất ngờ: chú lạc đà lại kéo theo một chiếc xe hơi sang trọng.

Nghịch lý thú vị và hợp lý, vì xe hơi đâu thể chạy trên cát sa mạc! Chiếc xe hơi tuy có đẹp, tốc độ nhanh nhưng với môi trường khắc nghiệt như trên sa mạc thì chưa chắc độ bền, sức dẻo dai đã bằng lạc đà.

Trong kinh doanh cũng vậy. Một doanh nghiệp nhỏ, có chi phí thấp, khả năng thích nghi cao có thể sẽ đi xa hơn một doanh nghiệp quy mô lớn, mức độ tăng trưởng vốn, doanh thu rất nhanh, nhưng tiềm ẩn chi phí lớn, chỉ cần một biến động nhỏ về doanh thu là có thể tạo nên xáo động lớn trong vận hành doanh nghiệp. Trong các điều kiện kinh doanh khó khăn, sức bền cạnh tranh của doanh nghiệp mới phát huy vai trò quan trọng của mình. Doanh nghiệp cũng cần thích ứng nhanh chóng, sẵn sàng thay đổi phương thức kinh doanh (phương tiện) để đạt tới mục tiêu tồn tại và phát triển.

Trở thành thành viên chính thức của Tổ chức Thương mại Thế giới (WTO) đưa nền kinh tế Việt Nam bước vào vào một kỷ nguyên mới: mở cửa kinh tế toàn diện và chấp nhận cạnh tranh. Nhưng WTO không chỉ là luồng gió mới, mà nó còn có thể là cơn bão lớn tàn phá những nơi nó đi qua! Một mặt, sẽ chỉ còn lại những doanh nghiệp có khả năng chịu đựng tốt, kịp tiến hóa để thích nghi và thích ứng một cách tích cực với thời tiết khắc nghiệt. Mặt khác, bằng việc chuẩn bị hóa các hành vi kinh doanh, quy hoạch chiến lược và sáng tạo liên tục để chống chọi với sự tàn phá, nền văn minh kinh doanh sẽ ra đời một cách tự nhiên, không do điều luật nào quy định, mà qua định luật cạnh tranh.

Có lẽ trên đây là những thông điệp cơ bản mà cuốn sách "Văn Minh Làm Giàu \& Nguồn Gốc Của Cải" của tiến sỹ Vương Quân Hoàng muốn chuyển tải đến độc giả.

Với mảng sách về kinh tế kinh doanh, có một thực tế là trên các kệ sách, các tác giả người Việt không nhiều. Phần đông là bản dịch từ tiếng nước ngoài, thiếu đồng nhất về thuật ngữ, khái niệm, đôi lúc còn có cả lỗi dịch thuật, tối nghĩa. Cũng bởi là sách nước ngoài nên có nhiều phần nội dung xa lạ với thực tiễn Việt Nam. Từ đó, hình thành tâm lý là cố tìm bản gốc tiếng nước ngoại để đọc với những tác phẩm nổi tiếng.

Chính vì vậy, cuốn sách của tiến sỹ Vương Quân Hoàng là một bất ngờ khá thú vị với những nội dung không thiếu tính học thuật nhưng gắn liền với thực tế kinh doanh tại 


\section{Việt Nam.}

Nội dung của sách chia thành bảy chương lớn, nhiệt thành ủng hộ tinh thần khởi nghiệp-kinh doanh, và qua đó, là tới quá trình phát triển kinh tế bền vững ở Việt Nam. Hiệu ứng tích cực về đồi mới, sáng tạo, tri thức, phương pháp, kỹ năng và tinh thần khởi nghiệp, dù có thể diễn ra trong một khoảng thời gian không ngắn, nhưng rồi sẽ đem lại một kết cục khả quan: văn hóa kinh doanh khỏe mạnh, đầy sức sống, chấp nhận cạnh tranh và phát triển bền vững.

Nhân sinh quan kinh doanh văn minh được bàn tới trong cuốn sách không chỉ tốt cho tinh thần kinh doanh mà còn hữu ích cho cuộc sống. Phương pháp và óc phân tích luôn quan trọng. Trong kinh doanh có lúc thành công, khi trục trặc, có thể mất hết gia tài và phá sản nhưng cũng có thể tạo dựng sự nghiệp, xây dựng gia sản và làm lại tất cả. Đời người cũng vậy, có sai lầm (rất nhiều) và có cơ hội sửa chữa sai lầm.

Cuốn sách được biên soạn trên hệ thống sắp chữ điện tử LaTeX. Chữ Việt UTF-8 sử dụng gói OmegaVN của TS. Nguyễn Hữu Phúc (Nhật Bản), thường được sử dụng để viết các công trình khoa học. Hệ thống LaTeX được sử dụng trong khâu biên soạn mang lại nhiều tiện ích cho độc giả như: Trích dẫn chuẩn xác, Mục lục đầy đủ, Tra cứu thuật ngữ thuận tiện.

Hy vọng cuốn sách trở thành tài liệu tham khảo, trao đổi, phản bác và suy ngẫm hữu ích của nhiều độc giả.

Link nội dung: https://dantri.com.vn/kinh-doanh/van-minh-lam-giau-tu-goc-nhin-cuamot-nguoi-viet-1185718983.htm 


\section{Tài liệu tham khảo:}

[1] Vương Quân Hoàng. (2007). Văn minh làm giàu \& nguồn gốc của cải. Nxb Chính trị quốc gia, Hà Nội.

[2] Vương Quân Hoàng, Ngô Phương Chí. (2000). Nguyên lý tài chính-toán của thị trường chứng khoán. Nxb Chính trị quốc gia, Hà Nội. 